Prepared in cooperation with the U.S. Department of Housing and Urban Development

\title{
CHIPS: A New Way to Monitor Colonias Along the United States-Mexico Border
}

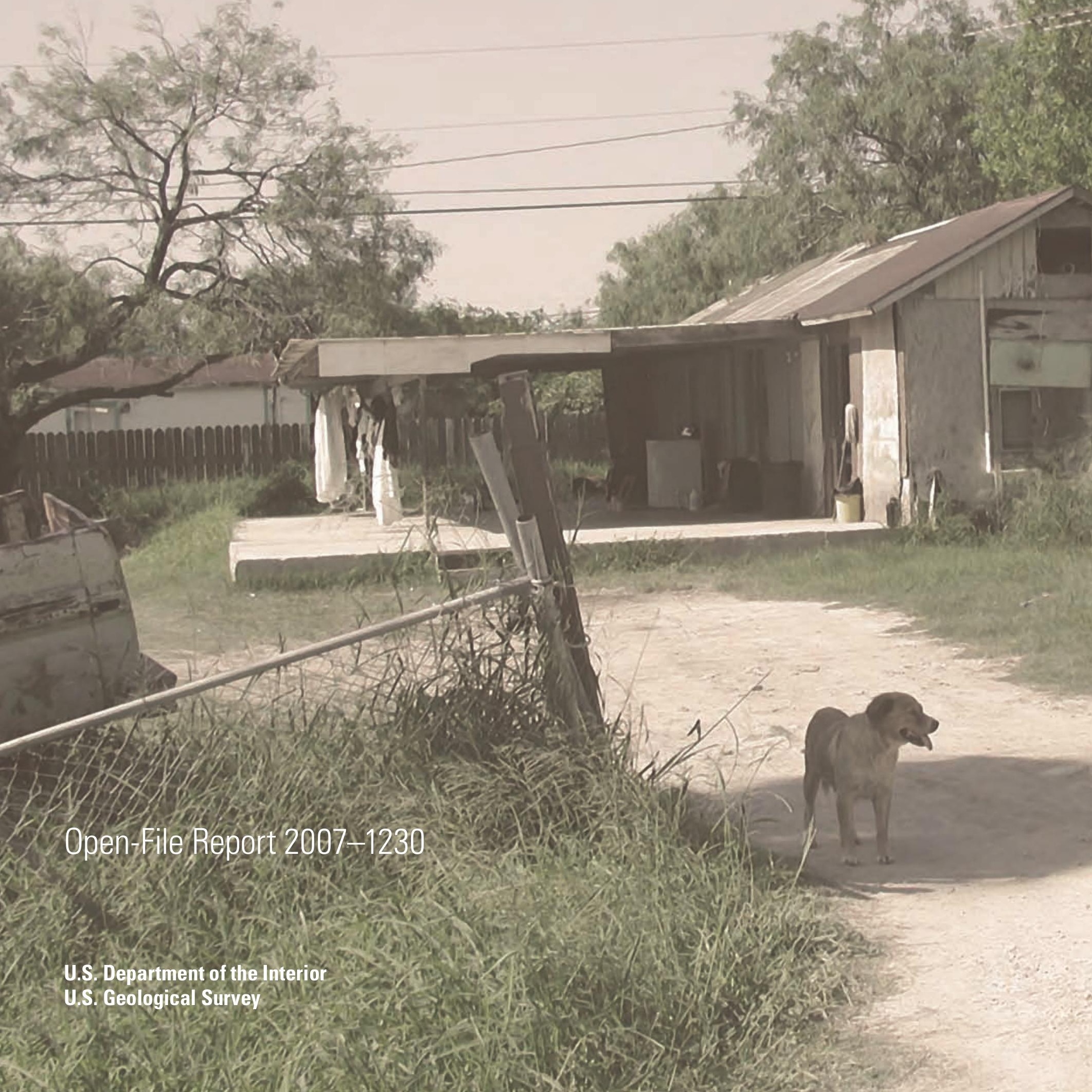


Covers. Housing structures located in colonias within Cameron and Hidalgo Counties, August 2005 (photographs by Jean W. Parcher, U.S. Geological Survey). 


\section{CHIPS: A New Way to Monitor Colonias Along the United States-Mexico Border}

By Jean W. Parcher and Delbert G. Humberson

Prepared in cooperation with the U.S. Department of Housing and Urban Development

Open-File Report 2007-1230 


\title{
U.S. Department of the Interior DIRK KEMPTHORNE, Secretary
}

\author{
U.S. Geological Survey \\ Mark D. Myers, Director
}

\section{U.S. Geological Survey, Reston, Virginia: 2007}

For product and ordering information:

World Wide Web: http://www.usgs.gov/pubprod

Telephone: 1-888-ASK-USGS

For more information on the USGS--the Federal source for science about the Earth, its natural and living resources, natural hazards, and the environment:

World Wide Web: http://www.usgs.gov

Telephone: 1-888-ASK-USGS

Any use of trade, product, or firm names is for descriptive purposes only and does not imply endorsement by the U.S. Government.

Although this report is in the public domain, permission must be secured from the individual copyright owners to reproduce any copyrighted materials contained within this report.

Suggested citation:

Parcher, J.W., and Humberson, D.G., CHIPS: A New Way to Monitor Colonias Along the United States-Mexico

Border: U.S. Geological Survey Open-File Report 2007-1230, 23 p. 


\section{Contents}

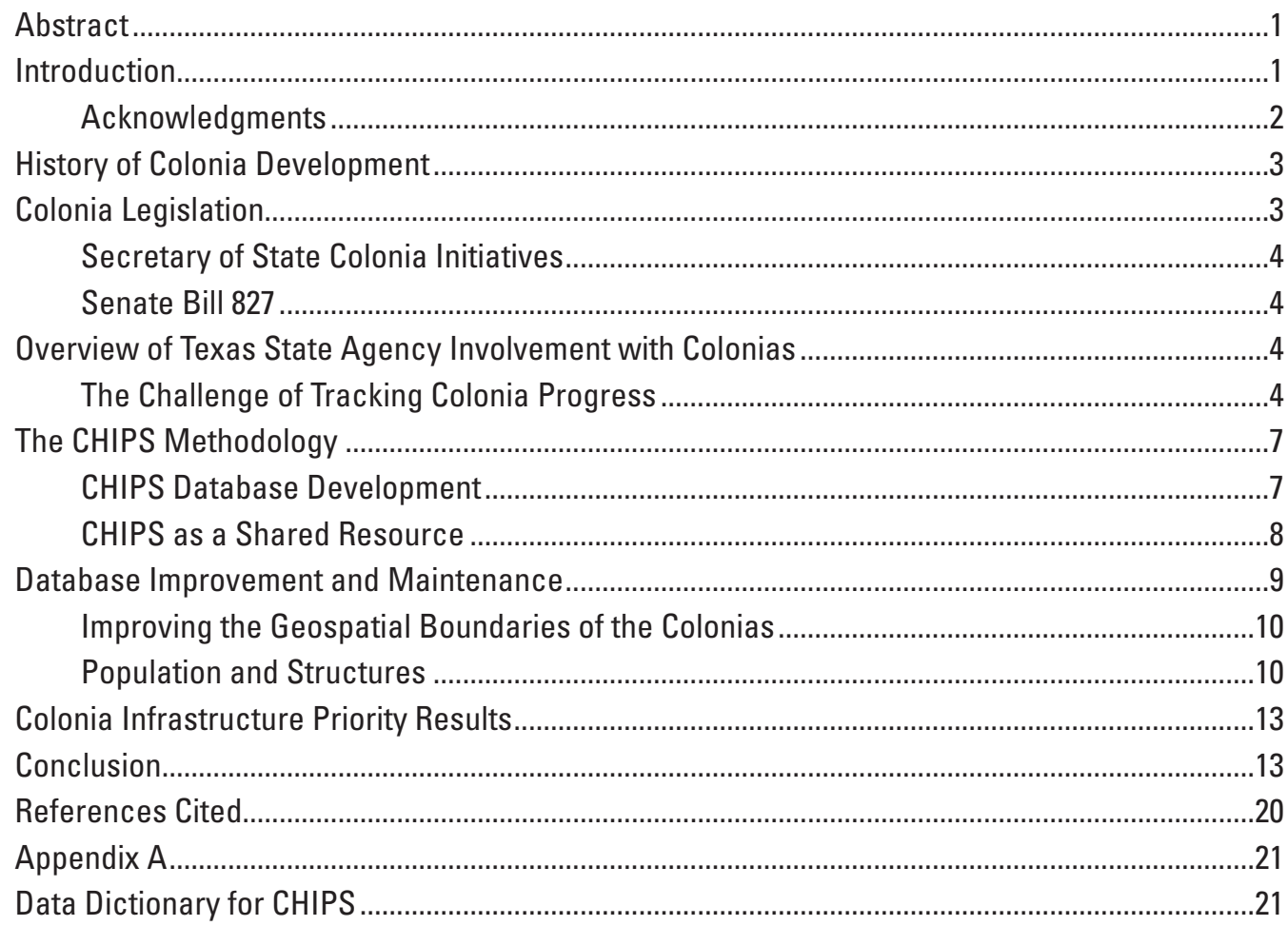

\section{Figures}

1. Map showing the location of colonias in Texas with $\mathbf{1 0 0}$ miles of the United States-Mexico border, 2003.

2. The demographic, infrastructure, and health criteria collected for each colonia as determined by the Senate Bill 827 Workgroup

3-5. Screen shots showing-

3. The database schema for the Colonia Health, Infrastructure, and Platting Status

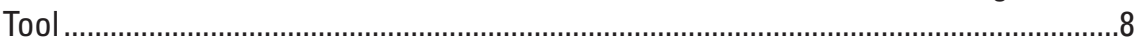

4. The graphic user interface used to enter colonia data ............................................

5. The custom report generator...............................................................................10

6. Map showing an updated colonia boundary compared to its previous boundary in El Paso County

7. Graph showing the distribution of green, yellow, and red colonias within the six counties contained in the Colonia Health, Infrastructure, and Platting Status tool (CHIPS)

8-13. Maps showing-

8. The distribution of green, yellow, and red colonias within Cameron County...................14

9. The distribution of green, yellow, and red colonias within El Paso County......................15

10. The distribution of green, yellow, and red colonias within Hidalgo County ....................16

11. The distribution of green, yellow, and red colonias within Maverick County ..................17

12. The distribution of green, yellow, and red colonias within Starr County .........................18

13. The distribution of green, yellow, and red colonias within Webb County........................19 


\section{Tables}

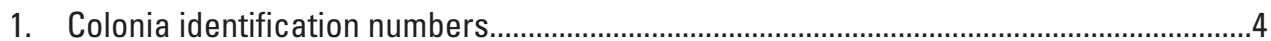

2. Classification criteria for colonias ............................................................................6

3. Summary of Texas Legislative Grant and Loan Programs ................................................6

4. Summary of Texas regulation and support agencies .......................................................6

\section{Conversion Factors}

\begin{tabular}{|c|c|c|}
\hline Multiply & By & To obtain \\
\hline \multicolumn{3}{|c|}{ Length } \\
\hline mile (mi) & 1.609 & kilometer $(\mathrm{km})$ \\
\hline \multicolumn{3}{|c|}{ Area } \\
\hline acre & 4,047 & square meter $\left(\mathrm{m}^{2}\right)$ \\
\hline acre & 0.4047 & hectare (ha) \\
\hline acre & 0.4047 & square hectometer $\left(\mathrm{hm}^{2}\right)$ \\
\hline acre & 0.004047 & square kilometer $\left(\mathrm{km}^{2}\right)$ \\
\hline
\end{tabular}




\title{
CHIPS: A New Way to Monitor Colonias Along the United States-Mexico Border
}

\author{
By Jean W. Parcher and Delbert G. Humberson
}

\section{Abstract}

Colonias, which are unincorporated border settlements in the United States, have emerged in rural areas without the governance and services normally provided by local government. Colonia residents live in poverty and lack adequate health care, potable water, and sanitation systems. These conditions create substantial health risks for colonias and surrounding communities. By 2001, more than 1,400 colonias were identified in Texas. Cooperation with the U.S. Department of Housing and Urban Development, Offices of the Texas Attorney General, Secretary of State, and the Texas Water Development Board has allowed the U.S. Geological Survey (USGS) to improve colonia Geographic Information System (GIS) boundaries and develop the Colonia Health, Infrastructure, and Platting Status tool (CHIPS). Together, the GIS boundaries and CHIPS aid the Texas government in prioritizing the limited funds that are available for infrastructure improvement. CHIPS's report generator can be tailored to the needs of the user, providing either broad or specific output. For example, a congressman could use CHIPS to list colonias with wastewater issues in a specific county, whereas a health researcher could list all colonias without clinical access. To help cities along the United States-Mexico border manage issues related to colonias growth, CHIPS will become publicly available in an Internetenabled GIS as part of a cooperative study between the USGS, the U.S. Department of Housing and Urban Development, and the Mexican Instituto Nacional de Estadística Geografía e Informática.

\section{Introduction}

The Handbook of Texas Online (<http://www.tsha.utexas. edu/handbook/online/>) defines colonias as unincorporated and unregulated settlements which emerged during the 1960s along the United States-Mexico border (Texas State Historical Association, 2003). Most colonias are located in Texas (more than 1,400 in 2001, fig. 1), but there are 80 in Arizona and 120 in New Mexico (Ward, 1999; Norman and others, 2006). The emergence of colonias within the U.S.-Mexico border region can be traced to the rapid growth associated with the Mexican Border Industrial Program during the 1960's. Increased economic growth on the Mexican side of the border fueled population expansion in the sister cities (Parcher, 2002). These transfrontier "sister" or "twin" cities are communities where a city in one country borders a city in another, creating a large urban area separated by administrative boundaries. This rapid population growth created a lack of affordable housing, causing new migrants in the United States to purchase rural homestead lots through a contract for deed program from land developers. Because of the need to keep prices affordable and the absence of effective land-use controls, these homesteads expanded into rural subdivisions without proper infrastructure (Davies and Holz, 1992). These substandard unincorporated subdivisions are commonly called colonias. Since the region is binationally interconnected economically, politically, and socially, the phenomenon of colonias in the United States is a transborder issue.

Population growth along the United States-Mexico border followed the world trend from a rural to a more urban environment (14 percent urban in 1900, almost 50 percent urban in 1990);(Douglas, 1994), with most of the population growth occurring in the major transfrontier cities. This uneven distribution of population growth left vast tracts of deserts, rangelands, and mountain regions with limited population (Forster and Cleveland, 2005). Demographic change within the border region is driven by United States and Mexican economic forces which are affected by global trends (Peach and Williams, 2003). Similar trends in United States and Mexican border demographics include greater than world average annual rates of growth (U.S. Census Bureau, 2006) during the 1990's (5 percent average annual growth for the Chihuahua, Coahuila and Baja California border region, 4 percent average annual growth for the Texas border region) characterized by young Hispanic migrants (Peach and Williams, 2003). This population growth, fueled by a source of inexpensive labor desiring home ownership (Davies, 1992), created peri-urban (land area on the fringe of a city) expansion in barren areas outside of municipal boundaries. Land developers profited from subdividing marginal rural areas without providing basic infrastructure services. The lack of county enforcement of proper land administration procedures allowed for the expansion of these 
Texas Colonias Within 100 Miles of the United States-Mexico Border, 2003

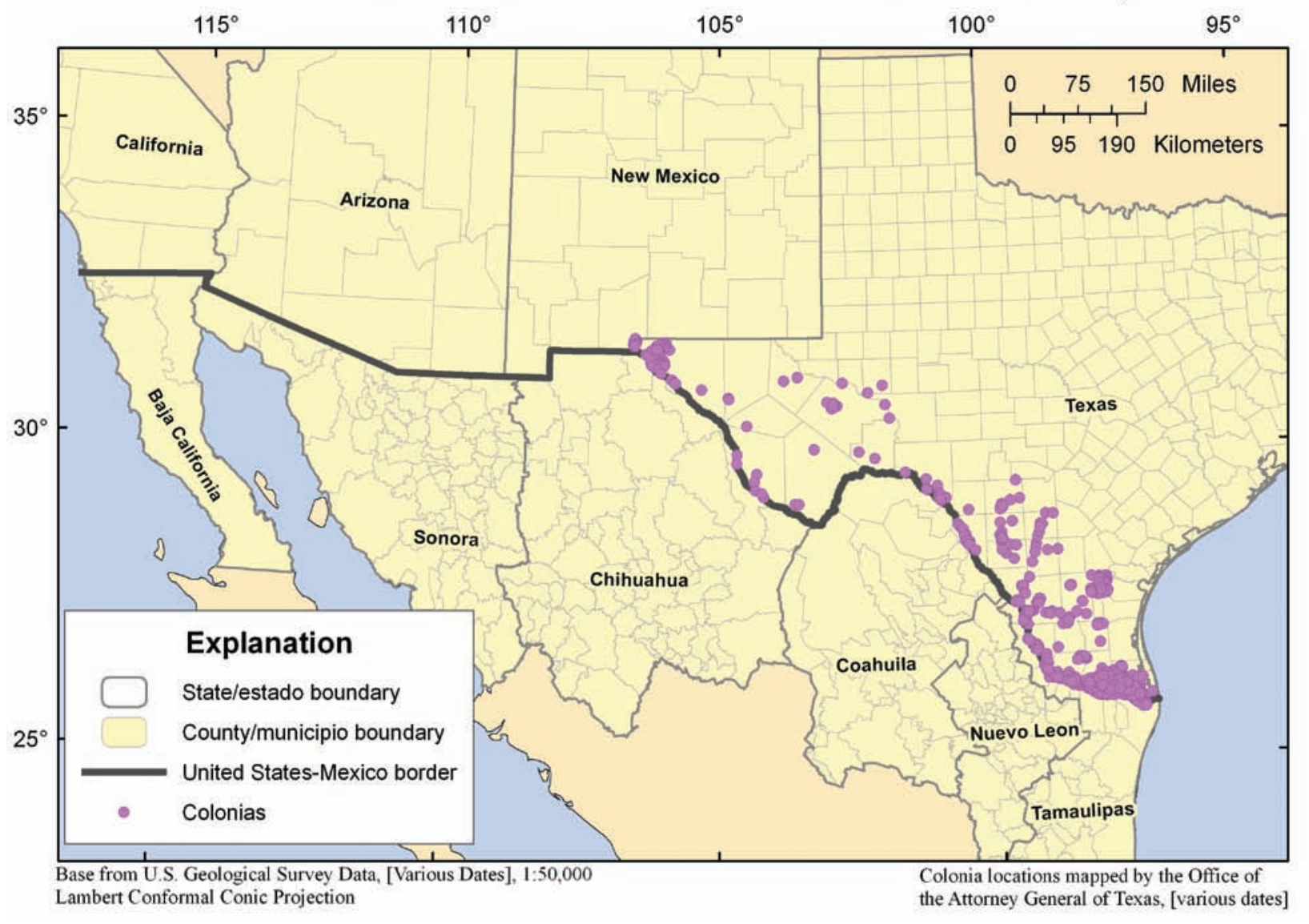

Figure 1. The location of colonias in Texas with 100 miles of the United States-Mexico border, 2003.

subdivided rural areas into colonias, which were affordable because of their rural location, but too costly for municipalities to provide infrastructure services.

Formalized land administration systems are critical components for societies to increase their market economies, plan for sustainable development, and reduce land conflict issues (Enemark, 2004; Deininger, 2004). The process of implementing land administration systems includes official recording of land tenure, land value, land use, and land development for each parcel (Van der Molen, 2004). Efficient and legal land administration systems aid in reducing land conflicts for societal groups that traditionally are discriminated against, and provide an efficient structure for delivering basic public services (Deininger, 2004). Many factors contributed to a breakdown of the land administration system during the 1970s and 1980s along the United States-Mexico border, which resulted in the explosion of colonias. These factors included: a lack of affordable housing opportunities, a largely migrant population without access to real-estate credit, differences in cultural practices, and insufficient county enforcement resources (Ward, 1999; Henneberger, 2000; Carter and Ortolano, 2004). Developers kept land prices affordable by restricting public infrastructure development; affordable pricing ensured a demand for colonia homesteads, even though the developers maintained the original title of the land until the contract for deed was paid in full (Ward, 1999; Carter and Ortolano, 2004). Therefore, in one of the richest countries in the world, the formalized land administration system was bypassed, which resulted in discrimination against the Hispanic migrant population, located in the poorest counties of the United States.

The unsanitary living conditions created by the lack of infrastructure in the colonias initiated a political movement by United States-Mexico border residents in the late 1980s. The goal of the movement was to lobby the Texas Legislature to support public funding for infrastructure improvements to alleviate third world settlements in the United States (Carter and Ortolano, 2004).

\section{Acknowledgments}

The authors would like to acknowledge the support of the Office of the Texas Secretary of State, Office of the Attorney General of Texas, and the Texas Water Development Board. Also, special recognition is deserved by the Office of the Texas Secretary of State colonia ombudsmen, who dedicated their time to collect the infrastructure data needed for the 
Texas Legislature report. Without the efforts of the aforementioned, this report would not have been possible.

\section{History of Colonia Development}

The key elements for colonia development included the need for affordable housing and the lack of county enforcement of land administration procedures (Ward, 1999). Since these makeshift settlements materialized on marginal agricultural land located far from incorporated cities, developers were able to lure low-income families to purchase a lot through a contract for deed. This allowed the residents to purchase the land with little or no down payment and to construct the permanent housing unit as funds became available (Ward, 1999; Carter and Ortolano, 2004). The contract for deed ensured that the land title remained with the developer until the loan had been paid in full; therefore foreclosure resulted in the land developer repossessing the land. Since settlements had been established outside the formally sanctioned governance of nearby cities and towns, county enforcement resources were insufficient to enforce the verbal agreements of the developer to follow through with public utility infrastructure needs. Texas colonia demographics consist of a majority of lowincome residents of Hispanic origin, with at least 65 percent holding United States citizenship (Ward, 1999; Salinas and others, 1988). Most are located outside of municipal boundaries in rural areas; therefore colonia residents traditionally have struggled to gain access to basic infrastructure services such as water and sanitary systems.

Lacking public infrastructure and suffering from extreme poverty, many colonia residents relied on unsanitary sources for water and wastewater disposal. Rapid population growth in the border region during the 1980s resulted in a population density too high to be supported by inadequate sanitary systems such as cesspools and septic systems. Medical professionals observed a rise in health issues such as dysentery, hepatitis, and tuberculosis among the colonia residents. The poverty, poor health, and lack of sanitation in the colonias became national issues during the public debates discussed during the passage of the North American Free Trade Agreement (NAFTA). Political pressure from local residents and non-governmental organizations (NGOs) to improve the living conditions of colonia residents resulted in the Texas state government taking action (Carter and Ortolano, 2004).

\section{Colonia Legislation}

In 1989 state and federal laws were passed to limit the expansion of colonias, and to provide funding to address their infrastructure needs. This legislation addressed various legal and infrastructure issues, but did not alleviate the problem of lack of affordable housing. The 71st Texas Legislature passed Senate Bill 2 in 1989 to restrict future development of colonias in Texas (Ward, 1999; Carter and Ortolano, 2004). Senate Bill 2 established the Economically Distressed Area Program (EDAP), which is administered by the Texas Water Development Board (TWDB). EDAP assistance grants can be obtained for communities with inadequate water or sewer systems located in counties with 25 percent unemployment and a per capita income 25 percent below state average. These grants provided the incentives for municipalities and utility companies to provide water and sewer systems to the colonias, many of which were located far from urbanized areas. Senate Bill 2 also enforced Model Subdivision Rules (MSR), which had to be adopted and enforced to receive EDAP funding. The MSR require that new subdivisions of land subdivided into tracts of 5 acres or less must provide adequate water and sewer infrastructure. MSR regulations apply to all subdivisions created after county adoption of the rules.

Another major reform was the Colonia Fair Land Sales Act that was passed as Senate Bill 336 during the 74th Texas Legislature Session, 1995 (Ward, 1999; Carter and Ortolano, 2004). Senate Bill 336 restricts the recession and foreclosure clauses and requires disclosure and bi-lingual availability of transactional documents for all contracts for deed legal affairs. Senate Bill 336 also allowed for converting the contract for deed to a mortgage when 40 percent of the purchase price, or 48 monthly installments, have been paid. This greatly reduced the number of foreclosures.

Even though the 10th Amendment to the Constitution in the United States empowers local governments to preside over land-use decisions, legislation was passed at the federal level to provide financial resources to alleviate extreme poverty in the colonias along the international border. In 1990 the U.S. Congress passed the Cranston-Gonzalez Affordable Housing Act, which stipulated that 10 percent of all Housing and Urban Development Community Development Block Grants be awarded to colonias project developments in the United States-Mexico Border states. The funding was passed to state government for distribution to local entities to improve colonia infrastructure and quality of life conditions. Even with proper legislation and financial assistance grants, the definition of a colonia was never agreed upon in Texas or within the United States. Each federal or state agency providing funding to a colonias initiative maintains their own definition of a colonia. This inconsistency is shown on the Office of the Texas Secretary of State colonias Web site: http://www.sos.state.tx.us border/colonias/what_colonia.shtml.

All definitions agree that colonias lack adequate water and sewer systems, but disagree on the geographic location of the colonias (within 150 miles of the border or in a county with per capita income 25 percent below state average) or on the size of a colonia (five or more housing units or population less than 10,000). On another issue, if a colonia receives sufficient infrastructure development, proper access to health care and education opportunities, and becomes incorporated into county or city governance, does it become a subdivision instead of a colonia? In other words, when is a colonia no longer a colonia? 


\section{Secretary of State Colonia Initiatives}

In 1999, Texas legislators passed Senate Bill 1421 in an effort to manage colonia infrastructure priorities for water and wastewater services. As a result, positions were created for a Director of Colonia Initiatives and six ombudsmen to serve under the Office of the Texas Secretary of State. The ombudsmen work in the six Texas counties with the highest colonia populations: Hidalgo, El Paso, Starr, Webb, Cameron and Maverick (Office of the Texas Secretary of State, 2006). Working with colonia residents, federal and state agencies, local governments, non-profit organizations, and utility companies, the ombudsmen coordinate meetings, monitor the status of water/wastewater projects, collect household information, and aid in the collection and review of required documents for agencies funding an infrastructure project. In addition to this, ombudsmen organize collaborative initiatives to provide needed services to colonia residents, such as medical and dental services (Office of the Texas Secretary of State, 2006).

\section{Senate Bill 827}

With the passing of Senate Bill 827 by the 79th Texas Legislature in 2005, the state was mandated to create a colonia identification system, and track the progress of state funded colonia improvement projects. These efforts were spearheaded by the Office of the Texas Secretary of State, and the Senate Bill 827 workgroup was formed. This workgroup consists of the Department of State Health Services, Health and Human Services Commission, Office of the Attorney General of Texas, Office of Rural Community Affairs, Texas Commission on Environmental Quality, Texas Department of Housing and Community Affairs, Texas Department of Transportation, Texas Water Development Board, and the Office of the Texas Secretary of State (Office of the Texas Secretary of State, 2006). To create a colonia identification system, the Office of the Texas Secretary of State adopted an existing identification system from the TWDB. With this system, each colonia is identified by a unique eight digit code beginning with the letter "M" followed by a seven digit numerical value. The first three numerical digits are the Texas county number for the colonia's county; the last four digits are numbers assigned in sequential order to the colonias (table 1).

To track the progress of state funded projects, the Senate Bill 827 workgroup created a set of infrastructure, demographic, and health-related criteria for the ombudsmen to collect in the six counties. These criteria were grouped into five sections (fig. 2), and aided in classifying colonias by the degree of health hazard that they pose, as well as track the overall progress of state-funded projects that have benefited colonias within 62 miles of the border. The ombudsmen collected data from a variety of sources, including site visits, utility companies, county appraisal districts, and the Office of the Attorney General of Texas.
Table 1. Colonia identification numbers.

\begin{tabular}{lc}
\hline $\begin{array}{c}\text { County name } \\
\text { (Texas county } \\
\text { number ) }\end{array}$ & \multicolumn{1}{c}{ Possible colonia identification numbers } \\
\hline Cameron (031) & $\{\mathrm{M} 0310001, \mathrm{M} 0310002, \mathrm{M} 0310003, \ldots, \mathrm{M} 0319999\}$ \\
El Paso (071) & $\{\mathrm{M} 0710001, \mathrm{M} 0710002, \mathrm{M} 0710003, \ldots, \mathrm{M} 0719999\}$ \\
Hidalgo (108) & $\{\mathrm{M} 1080001, \mathrm{M} 1080002, \mathrm{M} 1080003, \ldots, \mathrm{M} 1089999\}$ \\
Maverick (162) & $\{\mathrm{M} 1620001, \mathrm{M} 1620002, \mathrm{M} 1620003, \ldots, \mathrm{M} 1629999\}$ \\
Starr (214) & $\{\mathrm{M} 2140001, \mathrm{M} 2140002, \mathrm{M} 2140003, \ldots, \mathrm{M} 2149999\}$ \\
Webb (240) & $\{\mathrm{M} 2400001, \mathrm{M} 2400002, \mathrm{M} 2400003, \ldots, \mathrm{M} 2409999\}$ \\
\hline
\end{tabular}

Once the classification information was collected by the ombudsmen, colonias were to be classified based on health risk. This classification was interpreted by the Senate Bill 827 workgroup to mean a classification based on the status of their infrastructure (table 2).

\section{Overview of Texas State Agency Involvement with Colonias}

With the inception of the 1989 EDAP financial assistance legislation authorizing the TWDB to provide grants for water and wastewater projects, various other state agencies in Texas have become involved in colonias initiatives. To monitor the effectiveness of the programs, Senate Bill 827 requires the Office of the Texas Secretary of State to submit a report every 2 years to the legislature. The first report was submitted in December 2006. To develop the report and tracking system, the Senate Bill 827 workgroup and other invited agencies such as the USGS and the Center for Housing and Urban Development (CHUD) of the College of Architecture at Texas A\&M University met regularly on a monthly basis during 2006. The final report can be accessed at: http://www.sos.state.tx.us border/colonias/reports.shtm.

Section 4.0 of the Senate Bill 827 report provides detailed information concerning state agency legislative grant and loan programs for colonias (table 3 ).

In addition to financial support, various state agencies provide economic and community development assistance (table 4). For example, CHUD maintains three regional offices and 19 community resource centers along the border. These community resource centers provide social infrastructure services such as education, work force development, health and human services, and programs for youth, women, and elderly to enhance the ability of colonia residents to become self sufficient (Center for Housing and Urban Development, 2006).

\section{The Challenge of Tracking Colonia Progress}

The first comprehensive colonias database compilation for Texas was undertaken by the TWDB in 1992. Their 
1) Identification

County

Colonia ID \#

Colonia Name (s)

Est. Colonia Population

2) Platting

*If not in the TWDB/OAG Database, has the colonia been platted? (Y/N/Unknown)

If yes, has the plat been recorded? (Y/N/Unknown)

If yes, please provide the date it was recorded.

If no, does a map exist? (Y/N/Unknown)

If no, when was the community first established?

3) Infrastructure

Water

*How is potable water provided in this colonia?

Public water distribution system (Y/N/Partial)

Private wells? (Y/N/Partial)

Hauled in? (Y/N/Partial)

*Do all lots have a potable water supply? (Y/N)

Wastewater

*Is a wastewater collection system available in the colonia? (Y/N/Partial)

*Are there lots not served by adequate wastewater disposal? (Y/N/Partial)

Solid Waste Disposal

*Is a trash collection system available in the colonia? (Y/N/Partial)

Drainage

*Does the colonia flood during rainfall? (Y/N/Partial)

*Is any part of the colonia in a flood plain? (Y/N/Partial)

Roads

*Are the streets and roads passable in all weather conditions? (Y/N/)

*Are access roads from the colonia to public roads paved? (Y/N/Partial)

4) Access to, and Information about, Health

*Is it a health professional shortage area? (Y/N)

*Is there access to a Texas A\&M Community Resource Center, a clinic, mobile clinic or transportation to a clinic available? (Y/N)

*Are promotoras or a comparable outreach program available in the area? (Y/N/Partial)

5) Financial Availability

*List the federal and/or state agencies, non-profit organizations and other entities that are currently servicing the colonia and the type of project/service they are/will be providing.

Name of Agency Type of Project Service to be/being provided

1 .

2.

3.

Figure 2. The demographic, infrastructure, and health criteria collected for each colonia as determined by the Senate Bill 827 Workgroup. 
Table 2. Classification criteria for colonias.

\begin{tabular}{|c|c|c|}
\hline Degree of health risk & Classification level & Criteria \\
\hline High health risk & Red & $\begin{array}{l}\text { Satisfies at least one of the following: } \\
\text { 1. Either all or some lots have inadequate wastewater disposal (cesspools). } \\
\text { 2. All lots do not have a potable water supply. } \\
\text { 3. Not platted. }\end{array}$ \\
\hline Medium health risk & Yellow & $\begin{array}{l}\text { Platted colonias with a potable water supply and adequate wastewater disposal, and } \\
\text { satisfy at least one of the following: } \\
\text { 1. Either all or some lots lack solid waste disposal (trash collection). } \\
\text { 2. Not all roads are paved. } \\
\text { 3. Not all roads are passable in all weather conditions. } \\
\text { 4. It floods during a precipitation event. }\end{array}$ \\
\hline Low health risk & Green & $\begin{array}{l}\text { All lots satisfy all of the following criteria: } \\
\text { 1. Platted. } \\
\text { 2. Have a potable water supply. } \\
\text { 3. Have adequate wastewater disposal. } \\
\text { 4. Have solid waste disposal. } \\
\text { 5. All roads are paved. } \\
\text { 6. All roads are passable in all weather conditions. } \\
\text { 7. It doesn't flood during a precipitation event. }\end{array}$ \\
\hline
\end{tabular}

Table 3. Summary of Texas Legislative Grant and Loan Programs.

\begin{tabular}{|c|c|c|c|c|}
\hline Agency & Program & Federal cooperators & Date began & Services \\
\hline $\begin{array}{l}\text { Office of Rural and Com- } \\
\text { munity Affairs }\end{array}$ & Community Block Grants & Housing and Urban Development & 2002 & Infrastructure \\
\hline $\begin{array}{l}\text { Department of State } \\
\text { Health Services }\end{array}$ & Office of Border Health & $\begin{array}{l}\text { Center for Disease Control, The } \\
\text { Rensselaerville Institute }\end{array}$ & 1993 & Public Health \\
\hline $\begin{array}{l}\text { Texas Department of } \\
\text { Housing and Commu- } \\
\text { nity Services }\end{array}$ & Texas Bootstrap Program & Housing and Urban Development & Not available & $\begin{array}{l}\text { Mortgage assistance, } \\
\text { home repairs }\end{array}$ \\
\hline
\end{tabular}

Table 4. Summary of Texas regulation and support agencies.

\begin{tabular}{ll}
\multicolumn{1}{c}{ Agency } & \multicolumn{1}{c}{ Support services } \\
\hline Office of the Texas Secretary of State & Ombudsmen program \\
Office of the Attorney General of Texas & Enforcement of legislation, cartography \\
Health and Human Services & Human health services \\
Texas Commission of Environmental Quality & Certificates of convenience and necessity, Regulation of onsite sewerage, water \\
Texas A\&M Center for Housing and Urban Development & Community resource centers \\
\hline
\end{tabular}


goal was to identify eligible areas for water and wastewater infrastructure assistance under the EDAP. In the 37 border counties located within 100 kilometers of the border, the TWDB identified 1,193 colonias with an estimated population of 279,863 (Office of the Texas Secretary of State, 2006). This comprehensive report provided a baseline of water and wastewater infrastructure needs for state and federal policy makers to identify the scope of the problem. Further updates were made to the database in 1995 and 1996 by the TWDB.

To provide a geographic context, the Office of the Attorney General of Texas produced an extensive colonias geographic database with online maps at http://maps.oag. state.tx.us/colgeog, This geographic database used original plat maps and digital transportation files to georeference the location of the colonia boundaries. The TWDB comprehensive database was integrated into the Office of the Attorney General of Texas's geographic database by using similar unique colonia identifiers. The Office of the Attorney General of Texas worked with the U.S. Census Bureau in 2000 to include colonia areas in the census enumeration programs.

In 2003, the TWDB performed a revision of water and wastewater needs for colonias located in their EDAP designated counties. Procedures used to revise the database included contacting county local officials for infrastructure needs, integrating data from the county comprehensive data studies (produced through grants obtained from the Office of Rural Community Affairs), and contractor site visits. This revision identified 2,333 distressed areas with an estimated population of 484,892 . Of these distressed areas, 1,409 were identified, with an estimated population of 212,709 having inadequate water or substandard wastewater processes/treatments.

In 2003, the USGS began a study in cooperation with the U.S. Department of Housing and Urban Development (HUD) to build binational geospatial databases for select sister city areas along the United States-Mexico border. The project integrated the colonias geographic and infrastructure data into a regional context to provide city planners with the necessary information to estimate funding needs from federal agencies. In recognizing that Mexican border cities play an important economic role for the United States border cities, the binational aspect of the project provided information for regional planning. The USGS incorporated the TWDB and Office of the Attorney General of Texas databases into their project, and partnered with local government to share utility, transportation, and appraisal district data. These partnerships provided the mechanism to maintain local data and to improve the geographical boundaries for the colonias.

The EDAP database provided an excellent foundation for monitoring colonia development. Yet the different criteria collected to classify health risk level in the colonias for Senate Bill 827 required the development of a new database to store and analyze the current (2006) colonias data. Based on requirements outlined in Senate Bill 827, and in cooperation with the Office of the Texas Secretary of State, the USGS developed The Colonia Health, Infrastructure, and Platting Status tool (CHIPS) database of colonia conditions, using local government data initiatives and local ombudsmen information.

\section{The CHIPS Methodology}

Since colonias are not uniquely represented within the census geography, an explicit long term working database is needed to monitor progress, set infrastructure priorities, and measure quality of life indicators within the colonias. CHIPS uses a relational database to house the colonias data, which provides many benefits. For example, gathering data tables from multiple sources does not require manipulation of the datasets to force them into one table; instead, new tables remain their own separate entity. In addition to making data more manageable, this also helps prevent duplication of information because of repeated copying and pasting. The relational database also allows the use of Structured Query Language (SQL). Using SQL, users can manipulate how data are displayed without altering the original data tables. Another benefit is the database's open ended design, which facilitates the addition of data from other sources.

\section{CHIPS Database Development}

The classification criteria created by the Senate Bill 827 workgroup served as a template for the CHIPS's database schema. Essentially, the five classification categories were translated into five separate tables. For each table, a field was specified for each individual criterion and the tables were linked together by the unique identification numbers (fig. 3). Note that the five tables and their fields correspond with the criteria outlined by the Senate Bill 827 workgroup.

Under this schema, data entry rules and drop-down menus were created to facilitate data entry within a graphical user interface, which allows rapid data entry regardless of the user's level of familiarity with database structure (fig. 4). Using dropdown boxes ensures that all data are entered consistently, which allows for rapid querying. The top part of the graphical user interface contains the identification information and is always visible. The tabs labeled "Platting", "Infrastructure", "Health Care", "Financial Availability", and "Create Report" allow the user to choose the category to manipulate.

Because Senate Bill 827 requires a biennial report to be submitted by December 1st on even years, it is imperative that the data are stored in a format that is easily updatable and capable of generating custom reports rapidly. To accommodate this, two other functions were added to CHIPS. The first function provides CHIPS with the capability of updating the color classification of every colonia with a click of a single button. 


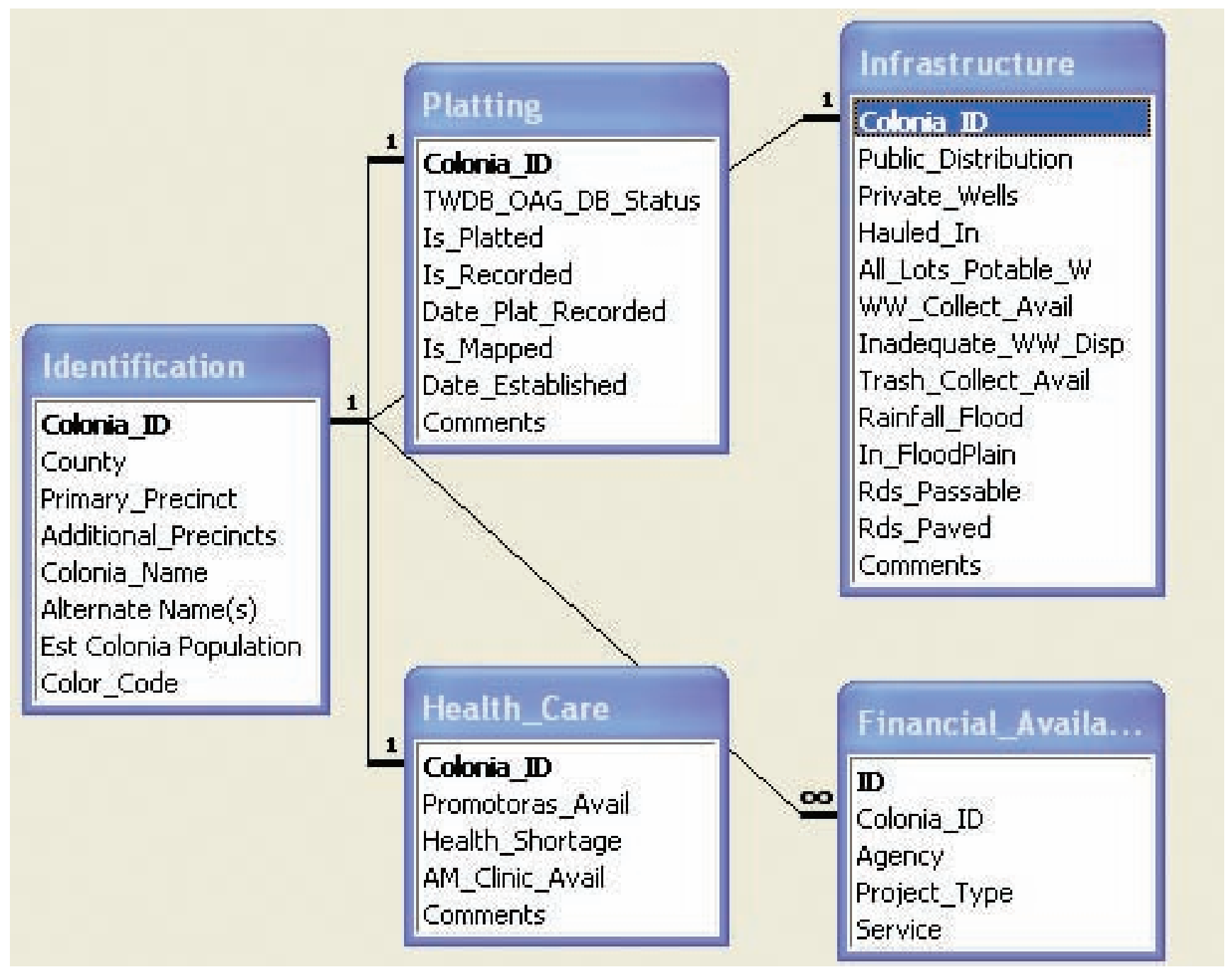

Figure 3. The database schema for the Colonia Health, Infrastructure, and Platting Status Tool.

This automated process eliminates any human error associated with attempting to manually classify thousands of colonias. This procedure is designed to be altered easily if the classification criteria change.

The second function is a custom report generator that is integrated into the graphical user interface. This allows users with little or no knowledge of SQL or database queries to extract information with ease. The report generator is flexible, and its output can be tailored to be either broad or specific. For example, a congressman could use CHIPS to list colonias with wastewater issues in a specific county, while a health researcher could list all colonias without clinical access (fig. $5)$.

Although CHIPS does not currently (2006) maintain a database of funds spent for infrastructure development, it has been designed to readily accept a financial data table with links to each colonia. This information could be entered and displayed by clicking on the fourth tab in the upper left corner labeled "Financial Ability". This is the next step in the database's development, and is being explored by the Office of the Attorney General of Texas and the Office of the Texas Secretary of State. Finally, although CHIPS is a powerful tool, it would have been impossible without the dedication and hard work of the Colonia Ombudsmen.

\section{CHIPS as a Shared Resource}

The USGS provided technical support by developing CHIPS's database and report generator for the Senate Bill 827 Colonias Initiative report. The Office of the Texas Secretary of State's Colonia Initiative populated CHIPS with data, and incorporated the results into the Senate Bill 827 Colonias Initiative report for the Texas Legislature. As of February 2007, CHIPS is under the auspices of the Office of the Texas Secretary of State. The Office of the Attorney General of 
Eg Colonia Information Entry

\section{$-\square \times$}

\section{Colonia Health Infrastructure Platting Status Tool}

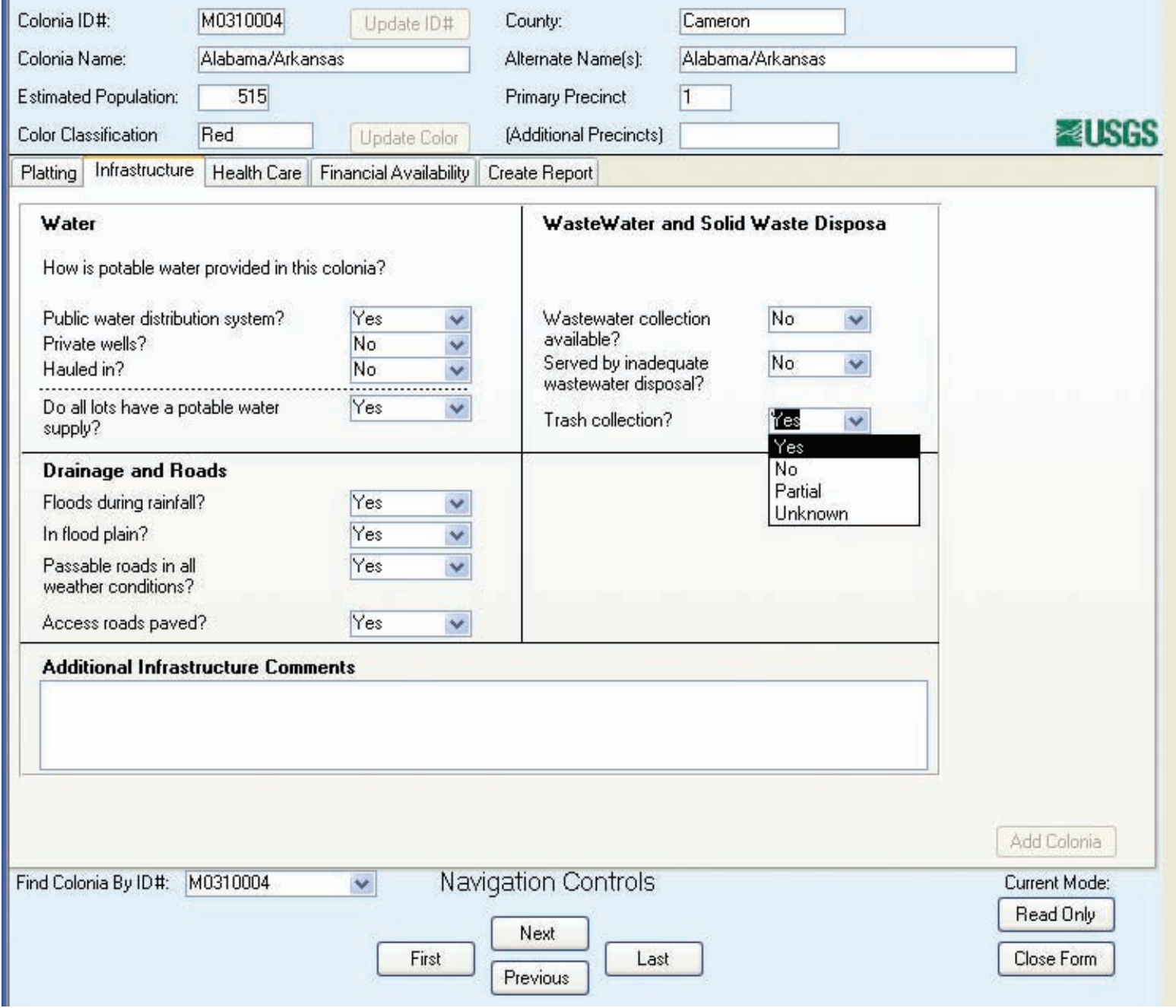

Figure 4. The graphic user interface used to enter colonia data.

Texas plans to incorporate the infrastructure information with their Colonias geographic database. The version of CHIPS used for the Senate Bill 827 Colonias Initiative report can be downloaded from http://borderhealth.cr.usgs.gov/datalayers. htm,

In 2007, the $80^{\text {th }}$ Texas Legislature passed Senate Bill 99, which mandates state agencies to report the status of water, wastewater, and other infrastructure projects in colonias to the Office of the Texas Secretary of State, and requires an updated report to the Texas legislature concerning the progress of statefunded colonia projects every even number of years (Texas Legislature Online, 2007). CHIPS could serve as the database for storing the new infrastructure project information, and for generating reports.

\section{Database Improvement and Maintenance}

The dynamic nature of colonias requires a strategy for maintaining current information. Data collected at the county level should provide the most up-to-date source. The challenge is to incorporate current county level data in the maintenance and improvement of CHIPS, thereby alleviating the need for large sums of funding to update the database. The use of the M number (table 1) as a standard colonia identification system within Texas allows other agencies to collect specific information, such as health statistics, and link it to CHIPS. 


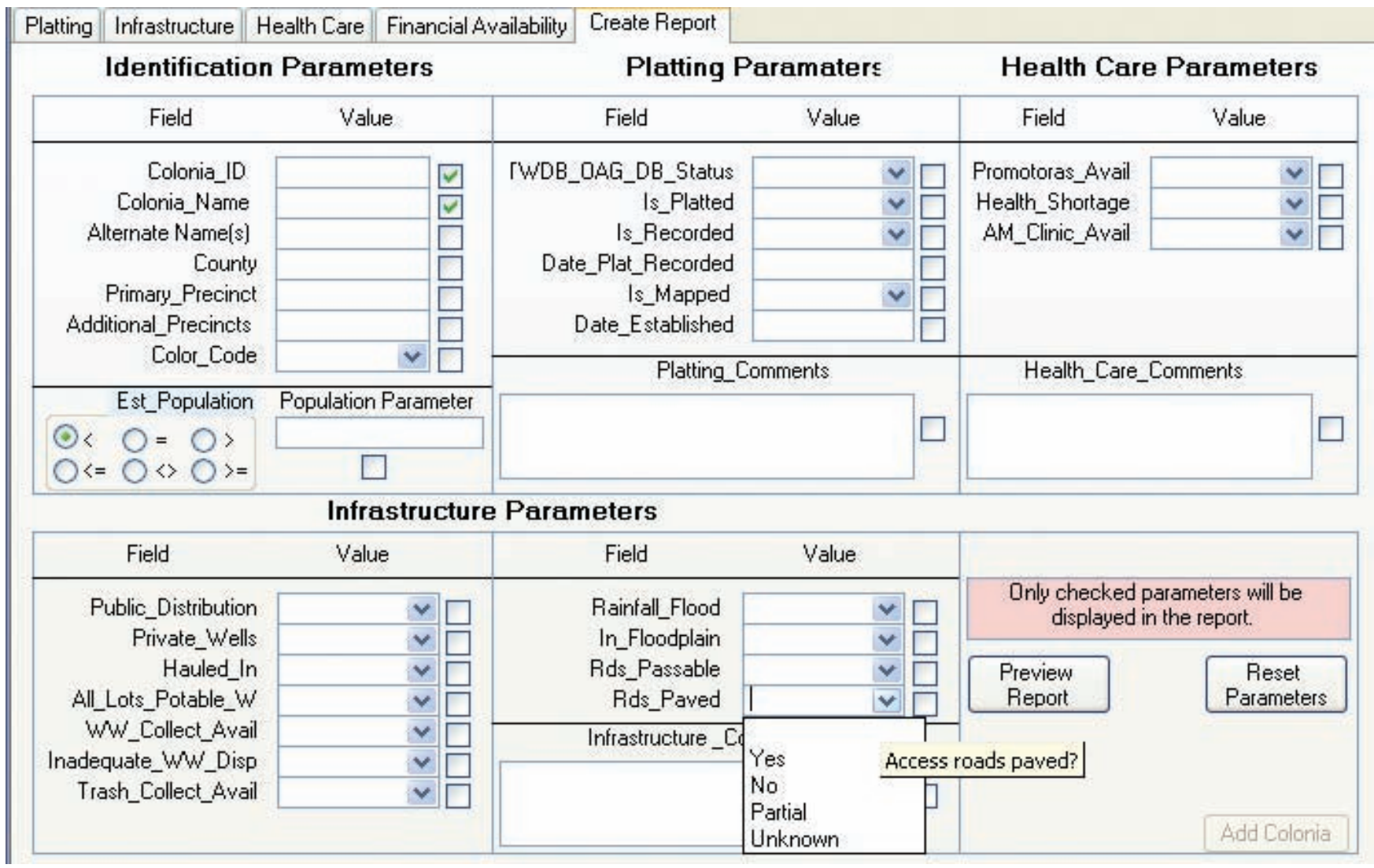

Figure 5. The custom report generator.

\section{Improving the Geospatial Boundaries of the Colonias}

In addition to CHIPS, accurate colonia boundaries are needed to monitor demographic changes, housing densities, and to serve as spatial references to existing infrastructure development. When the original GIS boundaries were created by the Office of the Attorney General of Texas, plat maps were used to get colonia outlines, which were georeferenced with electronic Emergency Medical Services maps. However, with the availability of more precise 2004 Digital Ortho Quarter Quad (DOQQ) imagery from the National Agriculture Imagery Program (NAIP), inaccuracies in the colonia locations were revealed. Working closely with the Office of the Attorney General of Texas, Maverick County Appraisal District, and El Paso County Appraisal District, the USGS updated the colonia boundaries in Maverick and El Paso counties. This was accomplished by using a combination of 2004 NAIP imagery and local appraisal district plat data (fig. 6).

\section{Population and Structures}

Accurately assessing demographic information for colonias is difficult. Because of confidentiality issues, colonia boundaries are not used for census enumeration units. Migrant employment creates absentee ownership and a mobile population. Various methods have been used to estimate population statistics for colonias. These include using aerial photos and remote sensing interpretation to count occupied structures and apply an average population estimate for each dwelling (Holz and Davies, 1992), door to door surveys (Ward, 1999), or a statistical allocation of 2000 census data based on proximity to transportation routes (Xiong, 2005). One of the limitations that exist for each method is the difficulty to track changes each year. The USGS piloted the use of digital county appraisal district data to estimate the number of occupied lots, which was suggested by the Maverick County Appraisal District (P. Medellin, oral commun., 2005). Appraisal district data are used to generate tax revenue; therefore, even economically disadvantaged counties invest in automated digital practices and maintain an up-to-date database. The USGS received a database listing of subdivisions in Maverick county with all platted lots, including information on whether or not an improvement exists on the lot. Matching the received subdivision names with a list of colonia names provided a method by which to count the total lots in each colonia and the number of improved lots in each colonia. Although this is not an explicit count of the number occupied lots, these data enabled us to derive an estimate by assuming that an improved lot is an occupied lot. To estimate 


\section{Schuman Estates, El Paso}

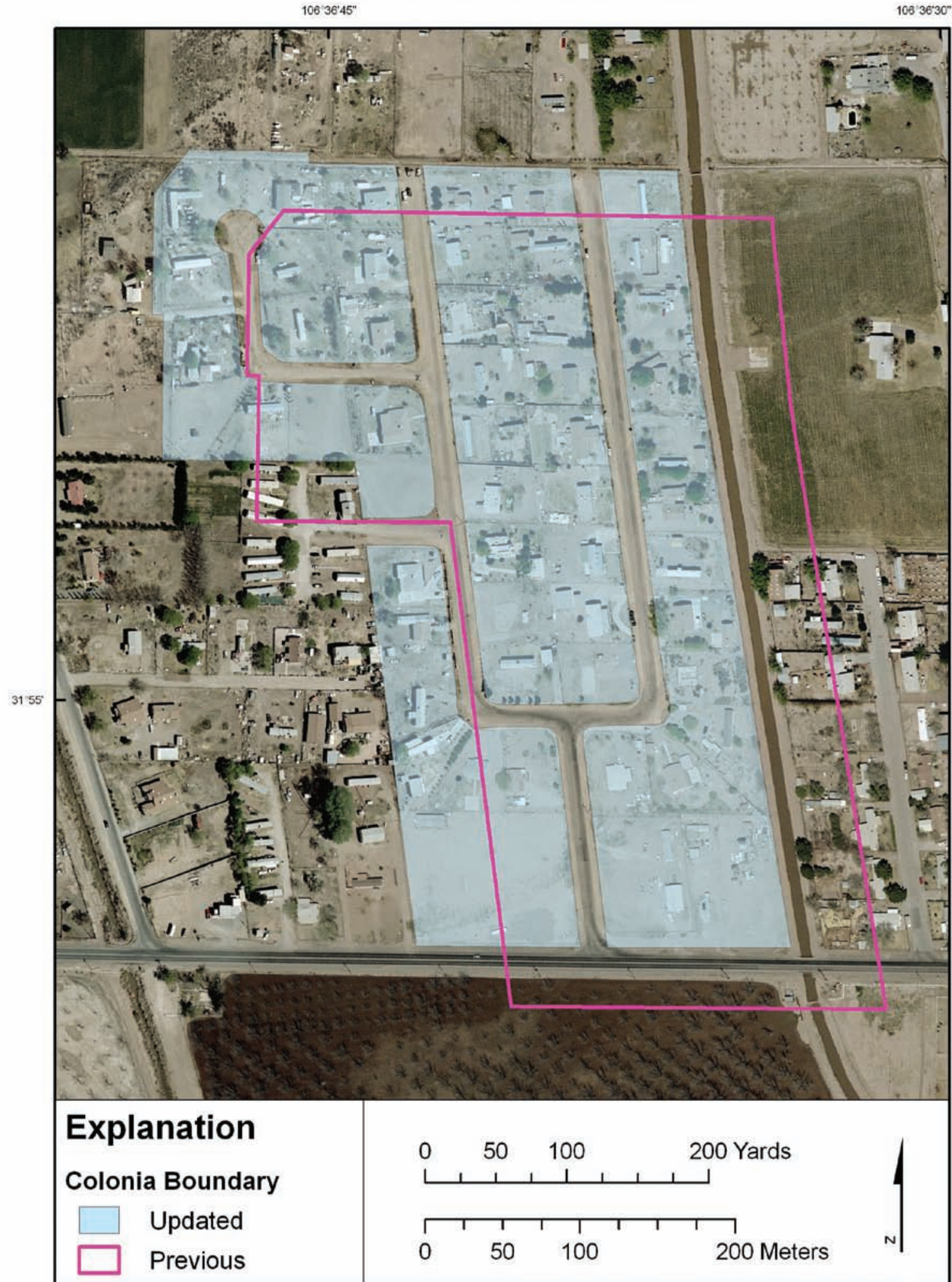

Base imagery from U.S. Geological Survey, 2002

Universal Transverse Mercator Projection

Previous boundaries were provided by the Office of the Attorney General of Texas, [various dates] Updated boundaries were provided by the EI Paso County Appraisal District, [various dates]

Figure 6. An updated colonia boundary compared to its previous boundary in El Paso County. 


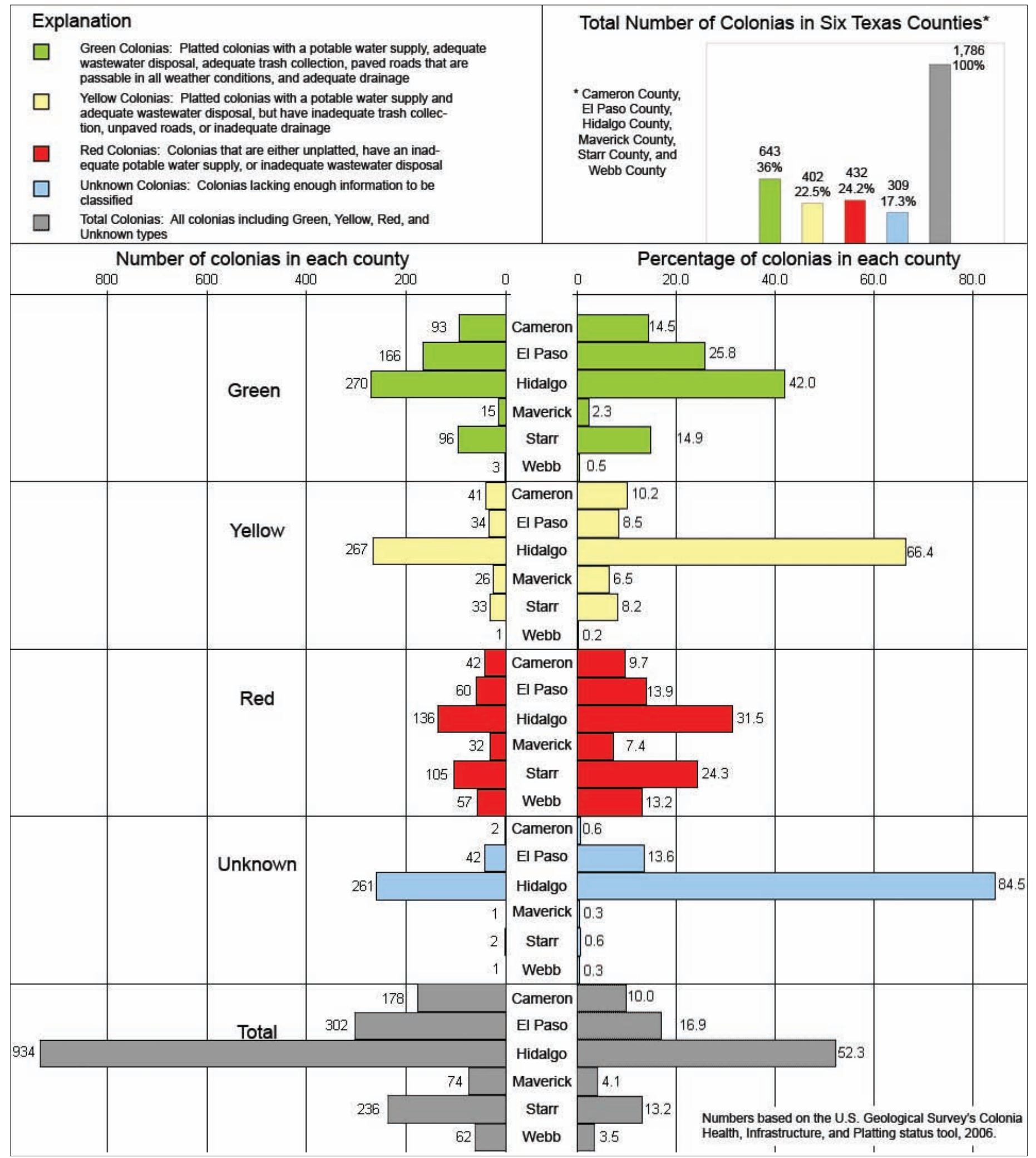

Figure 7. The distribution of green, yellow, and red colonias within the six counties contained in the Colonia Health, Infrastructure, and Platting Status tool (CHIPS). 
population, calculate the average population for each household and apply it to the number of improved lots.

\section{Colonia Infrastructure Priority Results}

The color classification of the colonias is fully automated by CHIPS. CHIPS calculates which colonias are red (high health risk), yellow (medium health risk) and green (low health risk) by using the health and infrastructure criteria provided by the Senate Bill 827 workgroup. The results of this classification display the distribution of the colors among the counties included in CHIPS, which are Cameron, El Paso, Hidalgo, Maverick, Starr, and Webb counties (fig. 7). Of the 1,786 colonias identified in CHIPS, 36 percent are identified as green, which is higher than the percentage of colonias identified as red (24.2 percent) or yellow (22.5 percent), but still less than the combined percentage of red and yellow colonias (46.7 percent). The report generator of CHIPS allows a quick comparison of the distribution of colonias between counties. For example, 10 percent of the colonias are located in Cameron county, but Cameron county has 14.5 percent of the green colonias; conversely, Maverick county has 4.1 percent of the colonias, but only 2.3 percent of the green colonias.

The results generated by CHIPS indicate where funds for colonia projects are most needed (fig. 8). Hidalgo County accounts for 84.5 percent of the unknown colonias in the six counties. This percentage represents 261 colonias where funding should be spent to collect current infrastructure data to properly classify the colonias. Once they are classified, a more meaningful distribution can be created and used to direct future funding.

Individual county maps depict the distribution of green, yellow, and red colonias within them (fig. 9-13). These maps show the trends within a single county rather than between different counties. With the exception of Cameron County, red colonias tend to be located away from major urban areas and transportation routes. This is not surprising since many red colonias are not connected to city water mains because of heavy construction costs; however, several red colonias are intermingled with green ones in Cameron County. These warrant extra investigation since the costs involved with connecting them to adequate water and wastewater lines would be relatively minimal.

In addition to the spatial distribution of the colonias, the maps also display the numerical distribution of the green, yellow, and red colonias. Cameron and El Paso counties have most of their colonias classified as green (52 percent and 55 percent, respectively), which reflects the progress that has been made in those counties as far as infrastructure improvement; however, more than 40 percent of the colonias in Cameron and $\mathrm{El}$ Paso counties still need improvement. Hidalgo County is more evenly distributed with 29 percent green, 29 percent yellow, and 15 percent red; but it is too early to estimate for Hidalgo County since 28 percent of the colonias remain classified as unknown. Maverick, Starr, and Webb counties have more colonias classified as red than any other color (43 percent, 44 percent, and 92 percent, respectively). Of the six counties in CHIPS, Maverick and Webb counties have the lowest number of colonias. If the state of Texas previously invested in projects for areas of large colonia density, these low numbers could explain the high ratio of red to green colonias. Should this be the case, CHIPS can help policy makers determine when to invest in these lesser populated areas as well.

\section{Conclusion}

As shown by Texas legislation, there is a need to track infrastructure, health, and quality of life indicators for colonia residents. This tracking system needs to measure performance of financial expenditures against actual improvements, and provide a method to determine future priorities. CHIPS can provide information to support infrastructure priorities. The output reports provide the information needed for planning and funding purposes. The maps and graphs created from CHIPS's database provide an intuitive manner to compare the distribution of red, yellow, and green colonias between counties, as well as within counties. The current (2006) results display the critical need to provide resources to identify the infrastructure status for the unknown colonias in Hidalgo County.

CHIPS's graphical user interface provides an easy method to analyze the data and update the information, even for those with limited database experience. The color classification process is fully automated, thus preventing human errors. The statewide colonias identification system provides a method to link other state agency databases to each individual colonia. Therefore, other agencies can maintain their own working database and link the information to CHIPS as needed for reporting purposes. For example, the Texas Department of Health Services can maintain disease statistics for a county with a summary of cases linked to the colonia identification system. Each agency in the Senate Bill 827 workgroup can track colonia financial expenditures in their agency database using the colonia identification system. Therefore, for the next biannual legislation, the financial expenditures could be generated easily for each colonia. To improve cooperation and reduce duplication, it is recommended that a single state agency be designated as the steward of the database.

Improvement to CHIPS could include better defined criteria for subjective information, such as road conditions during a flood. Also, inconsistencies exist between earlier databases and the information in CHIPS. Thus, ongoing quality-assessment and quality-control processes need to be continued to ensure the integrity of the database. As the data are revised, historical reports should be maintained for analyzing colonia improvement or deterioration.

Since the underlying issue for colonias is a lack of affordable housing, ongoing legislation may not have sufficiently addressed this problem. For example, with the conversion of the contract for deed into land title, and less 


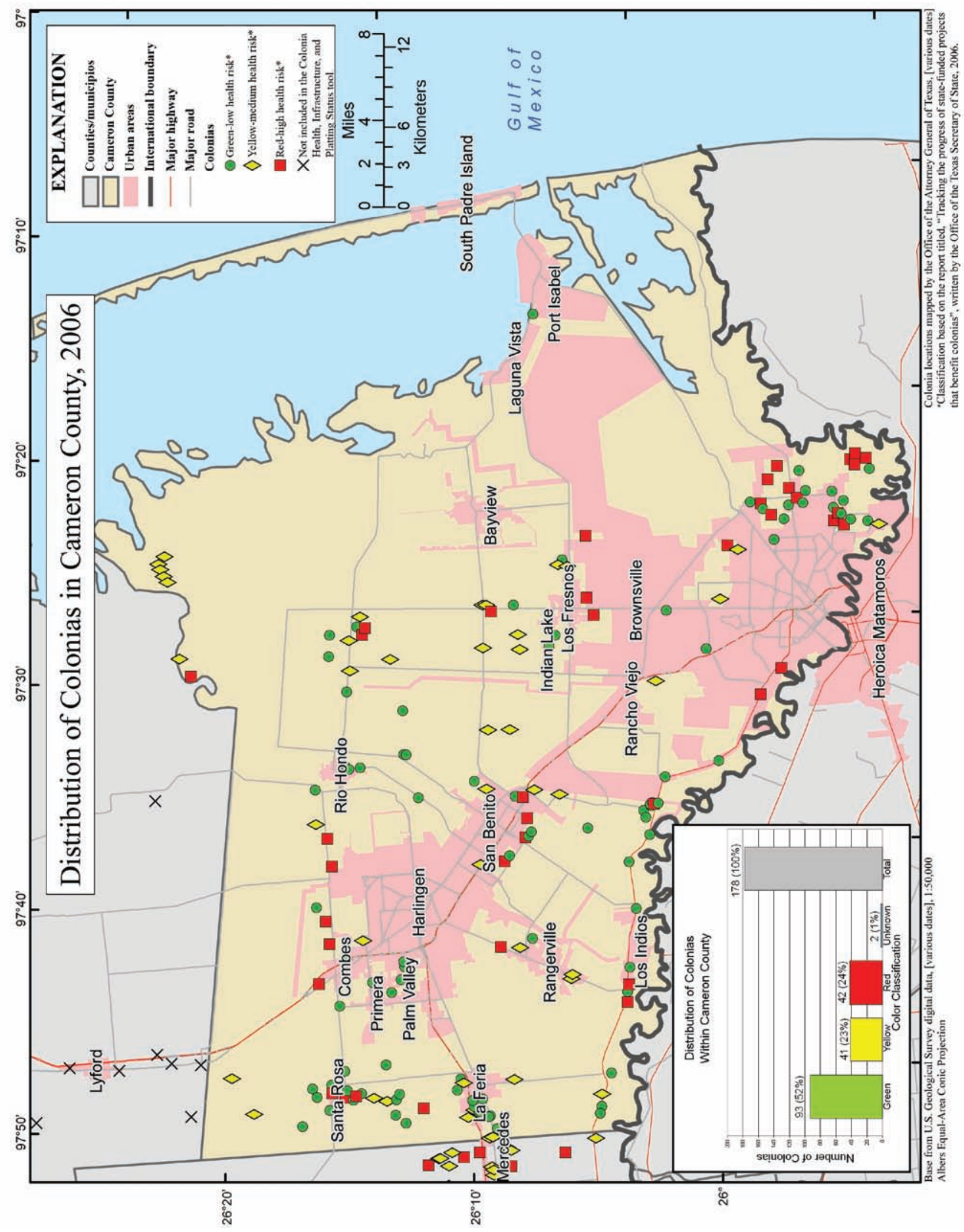

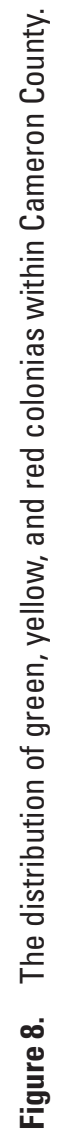




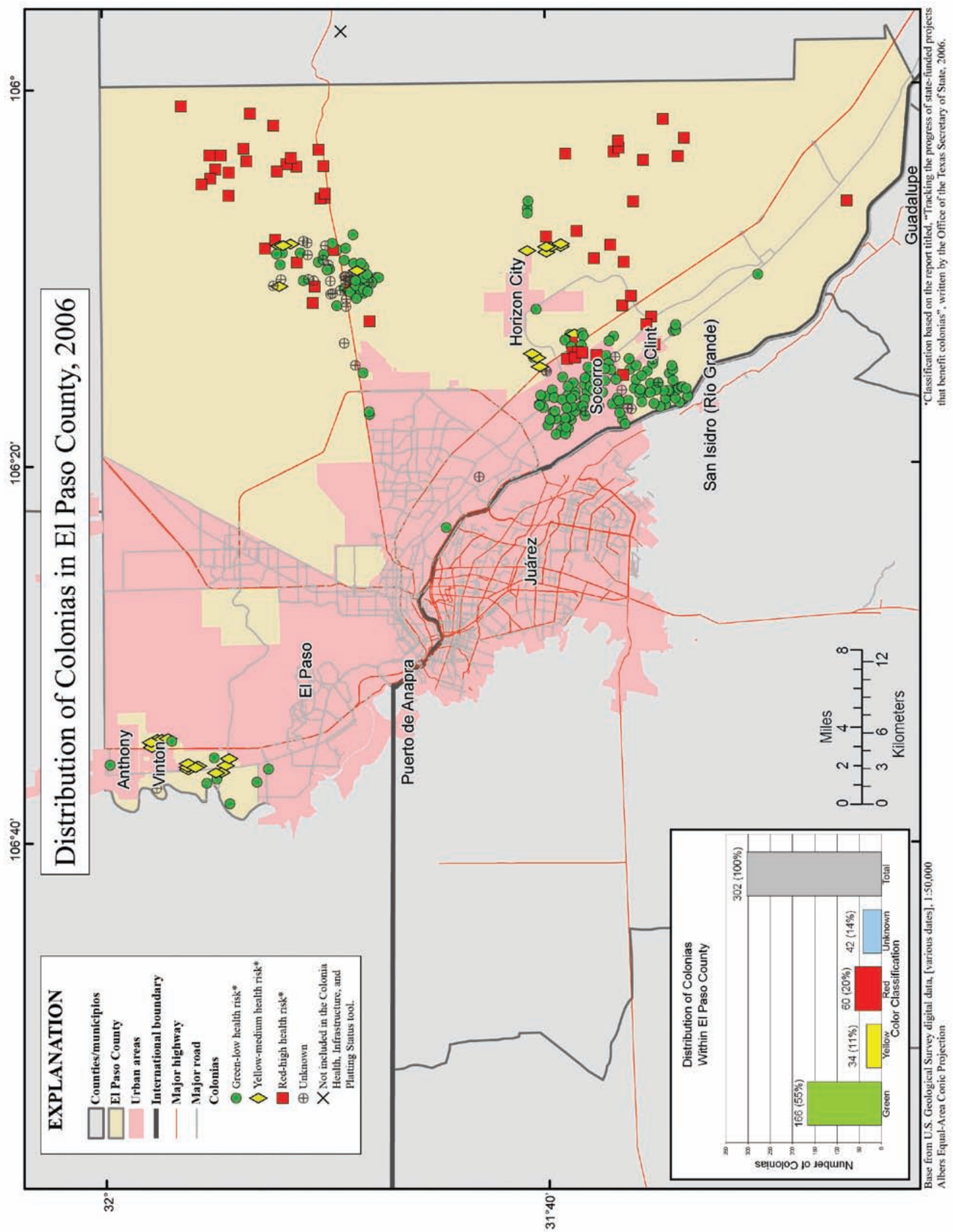

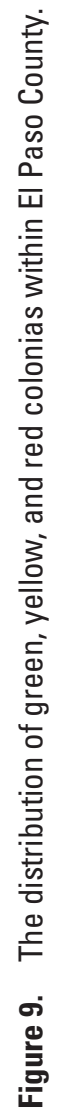




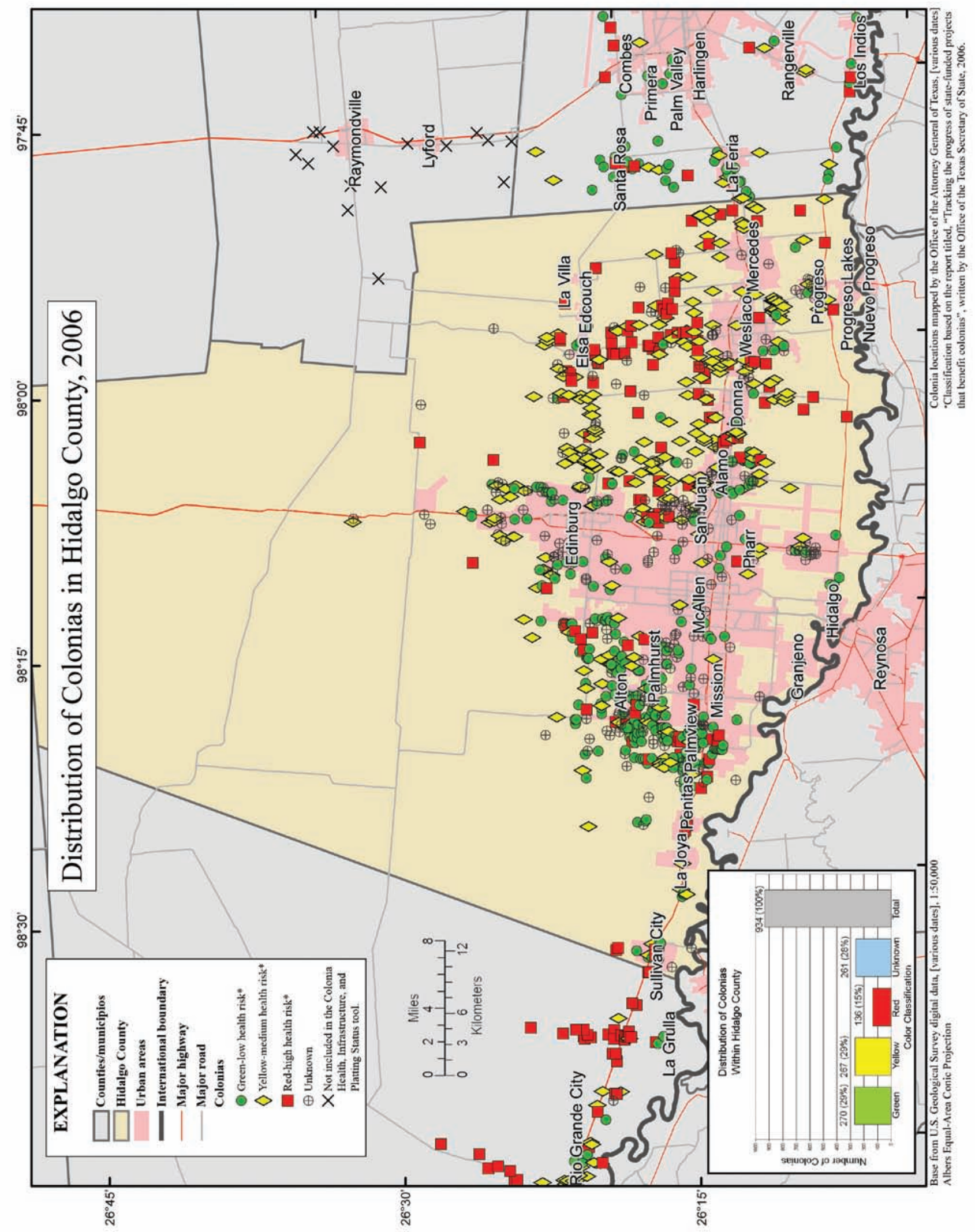

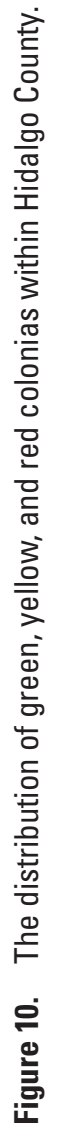




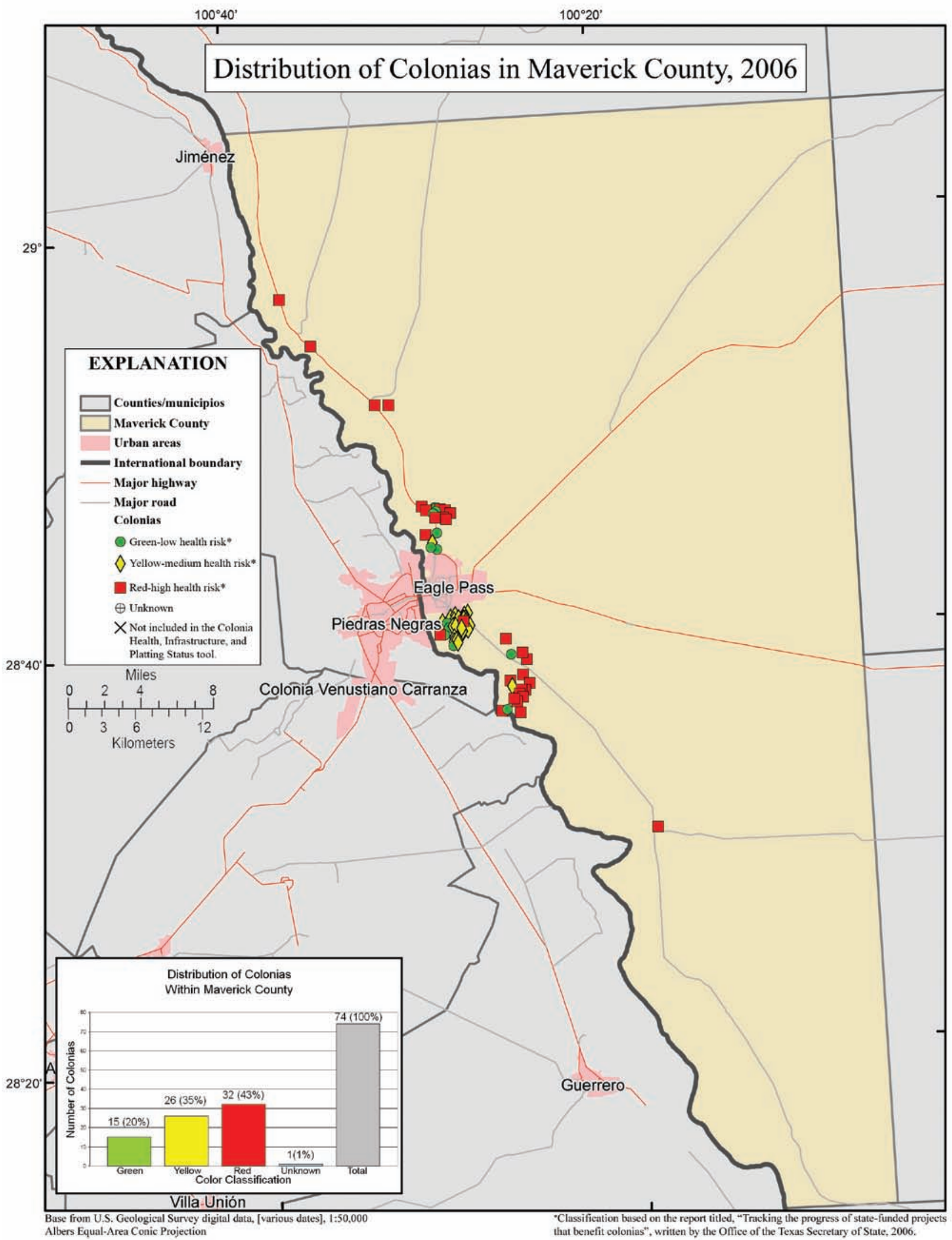

Figure 11. The distribution of green, yellow, and red colonias within Maverick County. 


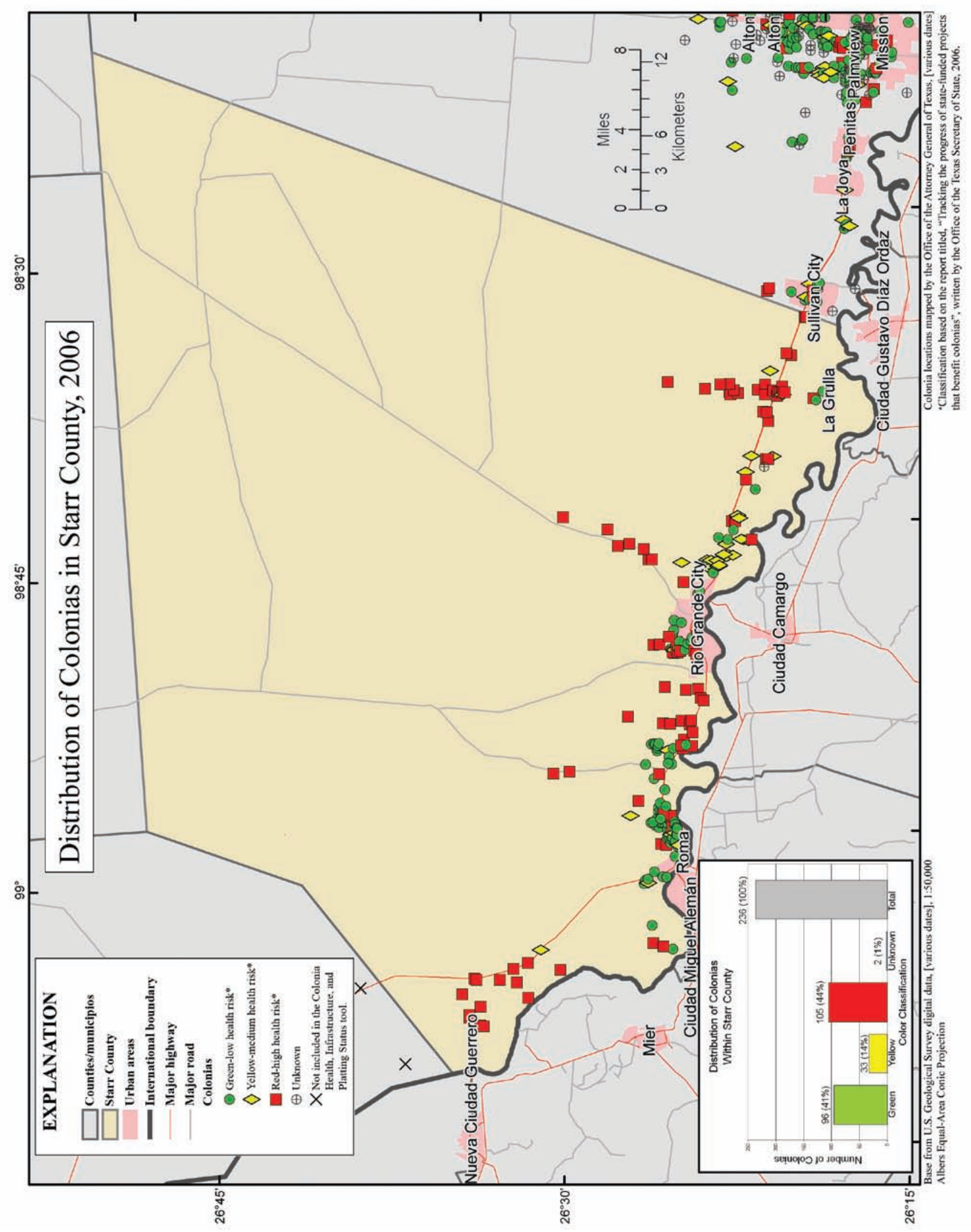

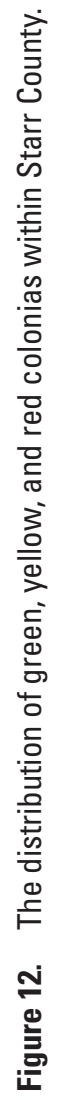




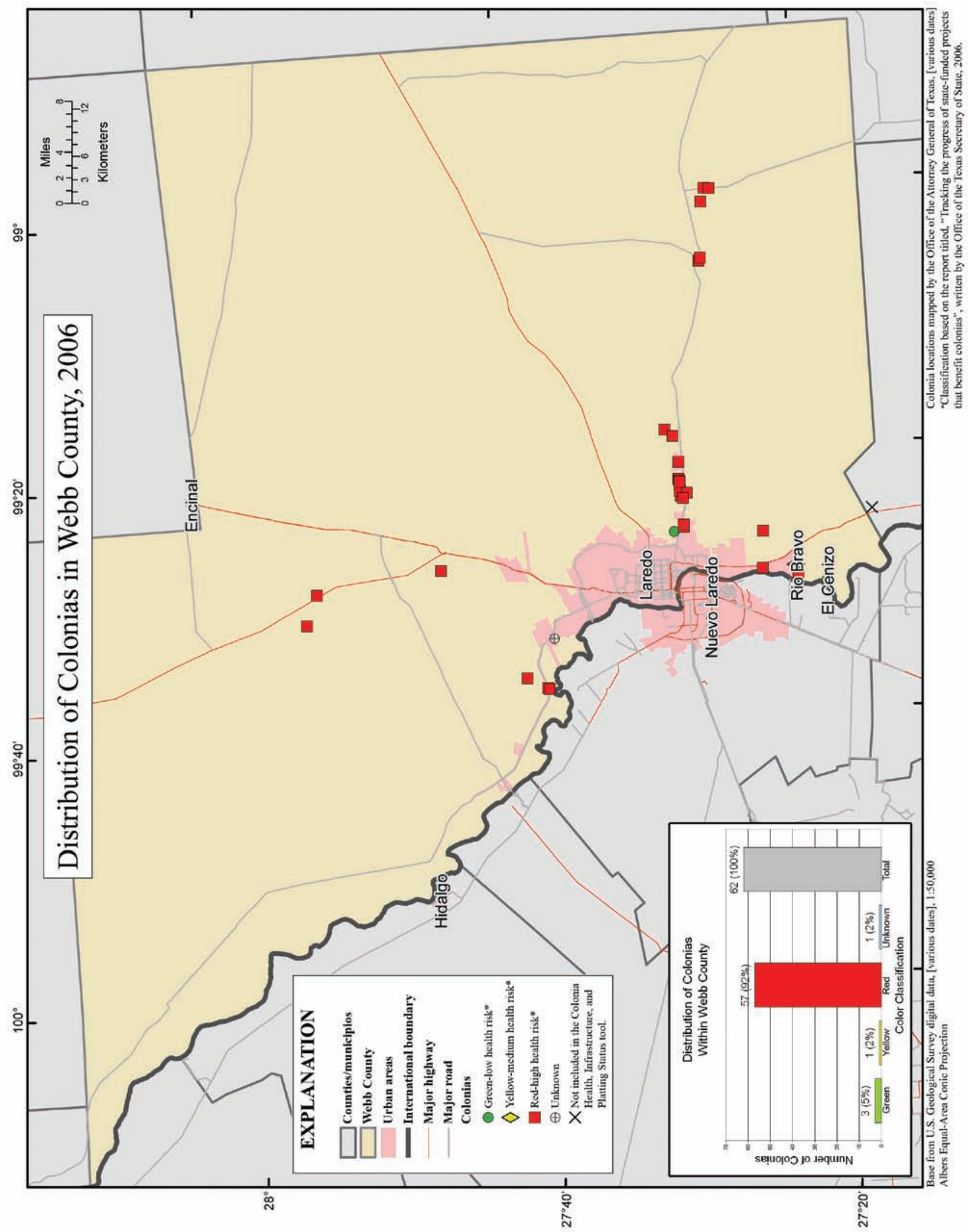

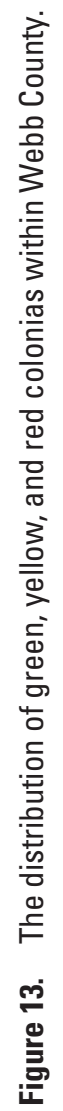


opportunities for new settlements because of the Model Subdivision Rule, colonia residents began to subdivide each colonia into smaller plats of land, many times occupied by related family members. With proper water and sanitation services, this would not result in overcrowding, but with cesspools and septic systems, a health hazard has resulted. This illustrates the need to closely monitor colonia infrastructure with a flexible tool capable of recording infrastructure changes and rapidly generating reports to monitor progress, which is a role wellsuited for CHIPS.

\section{References Cited}

Carter, N., and Ortolano, L., 2004, Implementing government assistance programs for water and sewer systems in Texas colonias: International Journal of Water Resources Development, v. 20, no. 4, p. 553-564.

Center for Housing and Urban Development, College of Architecture, Texas A\&M University, accessed July 7, 2007, at http://archone.tamu.edu/chud/Overview.htm

Davies, C.S., and Holz, R.K., 1992, Settlement evolution of "colonias" along the US-Mexico border, the case of the Lower Rio Grande Valley of Texas: Habitat International, v. 16, no. 4, p. 119-142.

Deininger, K.W., 2004, Land policies for growth and poverty reduction: Key issues and challenges ahead: Inter-regional Special Forum on the Building of Land Information Policies in the Americas: Aguascalientes, Mexico, October 26-27, 2004: accessed July 6, 2007, at http://www.fig.net/pub mexico/papers_eng/ts2_deininger_eng.pdd

Douglas, Ian, 1994, Human settlements: In Changes in Land Use and Land Cover: A Global Perspective: Press Syndicate of the University of Cambridge, p. 149-170.

Enemark, Stig, 2004, Building land information policies: Inter-regional Special Forum on the Building of Land Information Policies in the Americas: Aguascalientes, Mexico, October 26-27, 2004: accessed July 6, 2007, at http://www. ig.net/pub/mexico/papers_eng/ts2_enemark_eng.pdt

Forster, C.B., and Cleveland, N.L., 2005, Dynamics of human - environment interaction in the U.S.-Mexican border region: Southwest Consortium of Environmental Research and Policy Monograph 11: The U.S.-Mexico Border Region: Dynamics of Human-Environment Interactions: accessed July 5, 2007, at http://scerp.org/pubs/m11 chapter\%201-1.pds

Henneberger, John, 2000, Affordable housing on the border: Borderlines 65, v. 8, no. 3, accessed July 5, 2007, at http:// www.irc-online.org/us-mex/borderlines/2000/bl65/bl65.htm
Holz, R.K., and Davies, C.S., 1992, Remote sensing techniques for population estimation of colonias in the Lower Rio Grande Valley of Texas: Geocarto International (2), p. 21-32.

Norman, L.M., Donelson, A.J., Pfeifer, E.L., and Lam, A.H., 2006, Colonia development and land use change in Ambos Nogales, United States - Mexican Border: U.S. Geological Survey Open-File Report 2006-1112, 121 p.

Office of the Texas Secretary of State, 2006, Tracking the progress of state-funded projects that benefit colonias: accessed February 13, 2007, at http://www.sos.state.tx.ust border/colonias/reports.shtm

Parcher, J.W., 2002, Remote sensing method for estimating impervious cover for hydrologic modeling applications, A Case Study of the Brownsville, Matamoros Area: Masters Thesis, University of Texas, $158 \mathrm{p}$.

Peach, J., and Williams, J., 2003, Population and economic dynamics on the U.S.-Mexican border: past, present, and future: Southwest Consortium of Environmental Research and Policy Monograph 1: the U.S.-Mexico Border Region: A Road Map to a Sustainable 2020, accessed July 5, 2007, at http://scerp.org/pubs/mlc4.pd]

Salinas, E., Besenberg, M., Amazeen, J. 1988, The colonias factbook: A survey of living conditions in rural areas of south Texas and west Texas border counties: Texas Department of Human Services, 68 p.

Texas Legislature Online, 2007, Senate Bill 99: accessed July 31. 2007, at_tp://ftp.legis.state.tx.us/bills/80R/billtext/doct senate_bills/SB00001_SB00099d

Texas State Historical Association, 2003, The handbook of Texas online: accessed February 13, 2006, at http://www. tsha.utexas.edu/handbook/online

U.S. Census Bureau, 2006. Total mid-year population for the world: accessed July 9, 2007, at http://www.census.gov/ipc www/worldpop.htm

Van der Molen, Paul, 2004, Good administration of land in Europe: Inter-regional Special Forum on the Building of Land Information Policies in the Americas: Aguascalientes, Mexico October 26-27, 2004: accessed July 6, 2007, at http://www.fig.net/pub/mexico/papers_eng/ts3_molen_eng. pdd

Ward, P.M., 1999, Colonias and public policy in Texas and Mexico: Urbanization by stealth: Austin: University of Texas Press. 298 p.

Xiong, D., 2005, Allocation of census 2000 data to colonias: Oak Ridge National Laboratory, Oak Ridge, Tennessee, $51 \mathrm{p}$. 


\section{Appendix A}

\section{Data Dictionary for CHIPS}



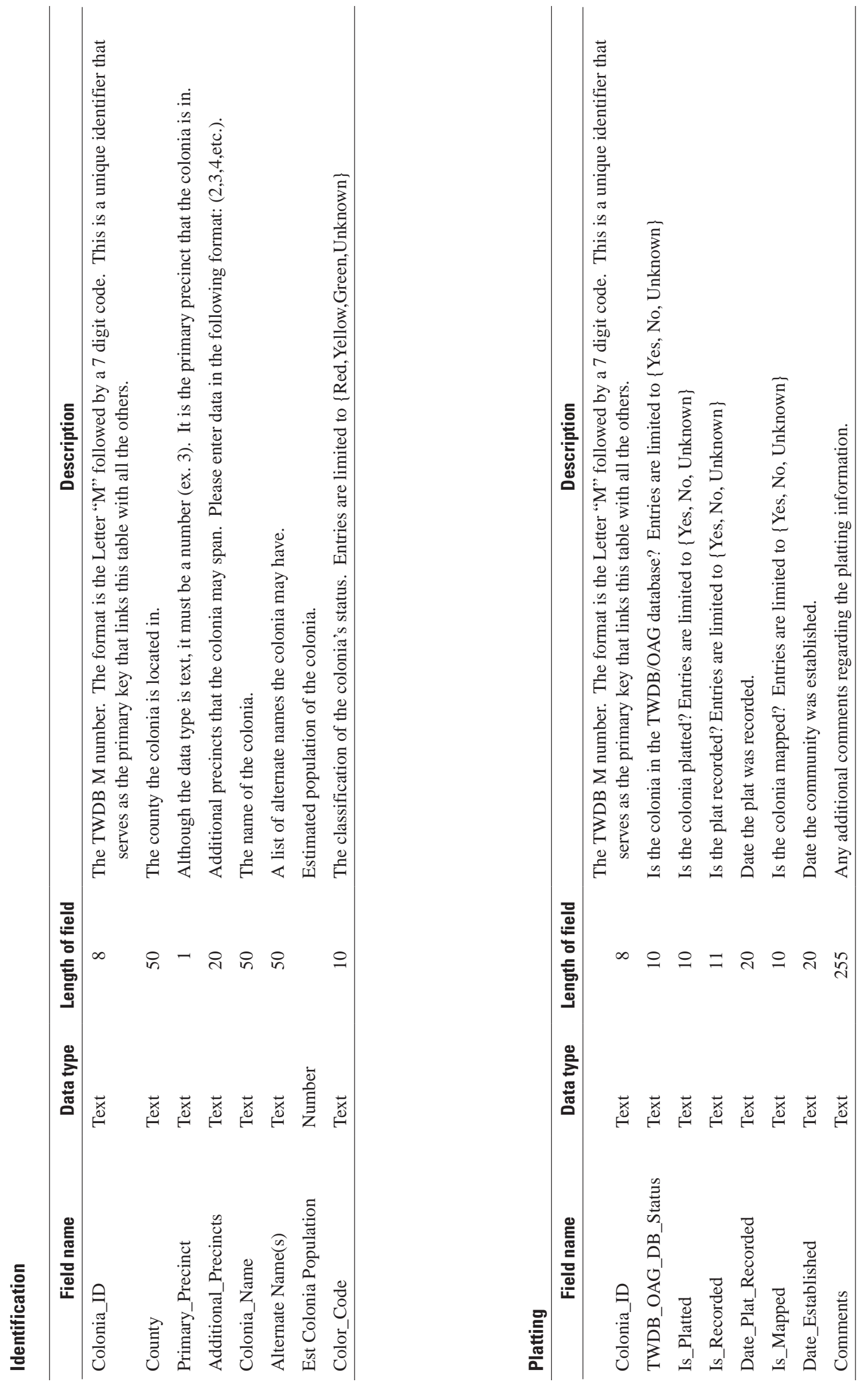

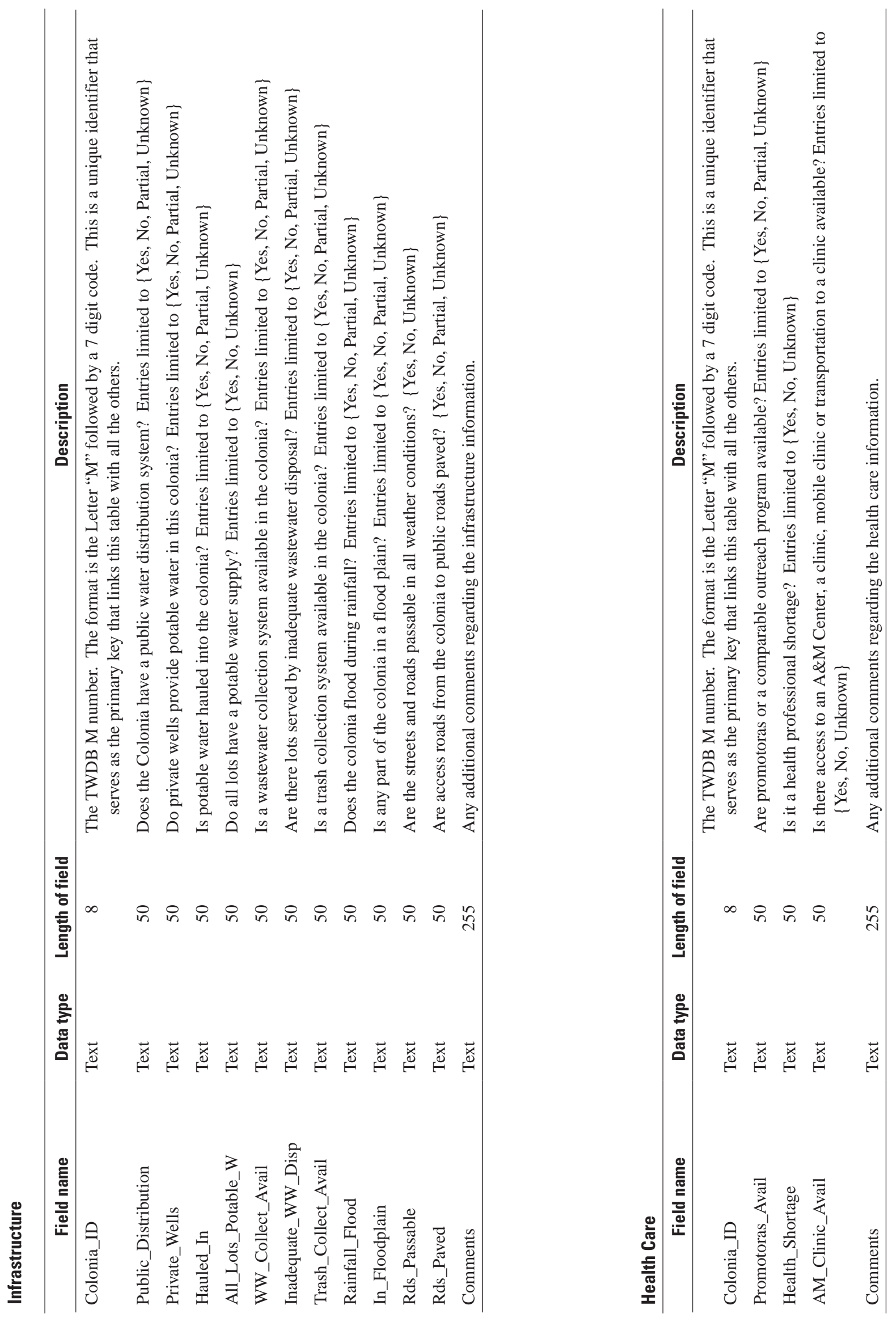
Prepared by:

USGS Enterprise Publishing Network

Rolla Publishing Service Center

1400 Independence Road

Rolla, M0 65401

For more information concerning this publication, contact:

Director

U.S. Geological Survey

Mid-Continent Geographic Science Center

1400 Independence Road

Rolla, MO 65401

(573) 308-3652

Or visit the Mid-Continent Geographic Science Center website at: http://mcmcweb.er.usgs.gov/mcgsc/ 



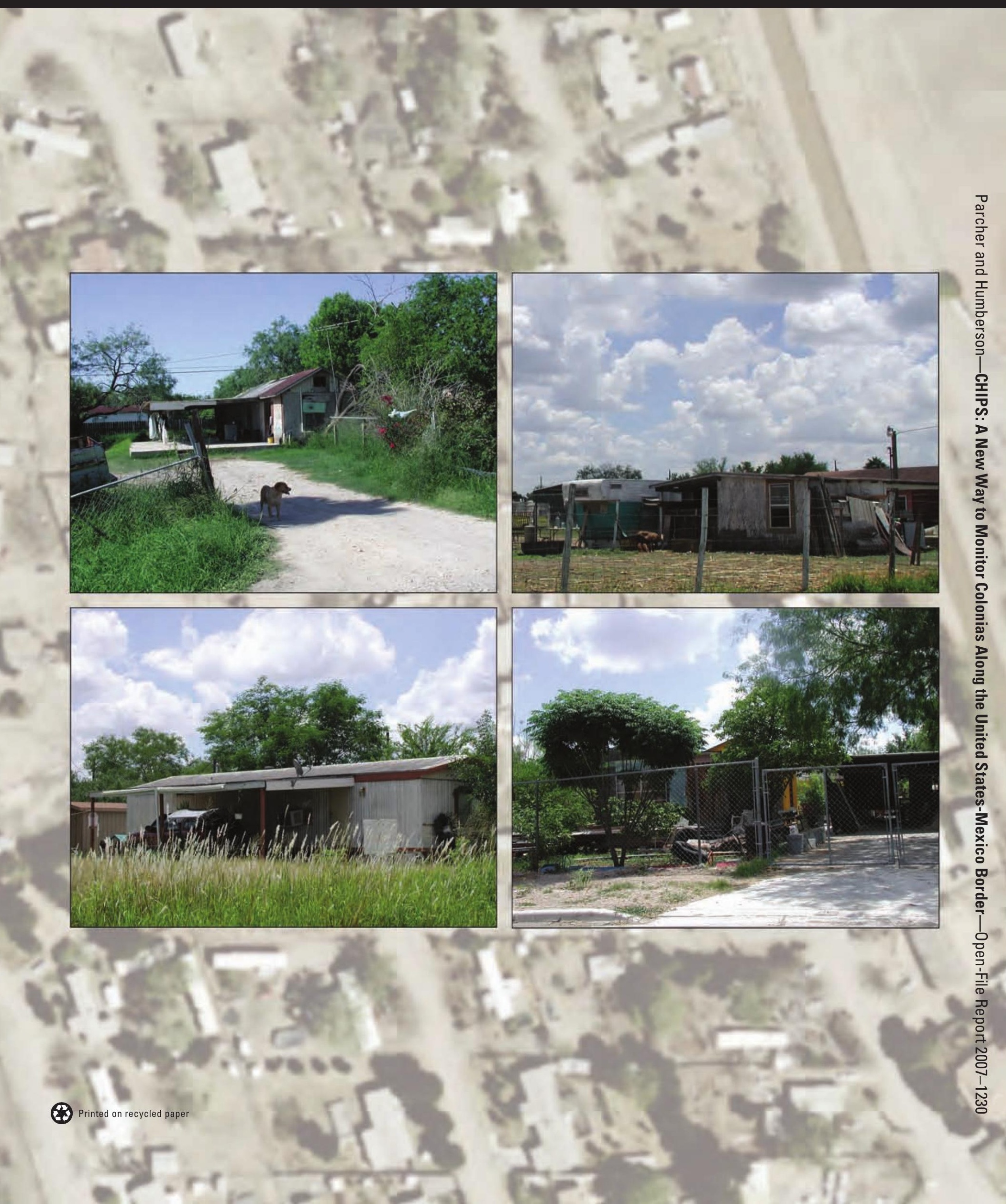

